\title{
Family-Centered Care and Positive Developmental Outcomes for Youth with Special Health Care Needs: Variations across Family Structures
}

\author{
Luke T. Russell, $\mathrm{PhD}^{1}$, Jonathon J. Beckmeyer, $\mathrm{PhD}^{2}$, \& Chang Su-Russell, $\mathrm{MA}^{3}$
}

${ }^{1}$ Assistant Teaching Professor, Department of Human Development and Family Science, University of Missouri, 410 Gentry Hall, Columbia, MO. Phone: (573) 882-1108 Fax: (573) 8845550 E-mail: russelllt@missouri.edu

${ }^{2}$ Assistant Professor, Department of Applied Health Science, Indiana University School of Public Health-Bloomington, PH 144, Bloomington, IN. Phone: (812) 856-4220 E-mail: jbeckmey@indiana.edu

${ }^{3}$ Ph.D. Candidate, Department of Human Development and Family Science, University of Missouri, 314 Gentry Hall, Columbia, MO. Phone: (573) 882-9513 Fax: (573) 884-5550 E-mail: cszm3@mail.missouri.edu

Keywords: Chronic Illness; Families with adolescents; Family caregivers; Quantitative 


\section{Biographical Paragraphs}

Luke T. Russell, PhD, is an assistant teaching professor in Human Development and Family Science at the University of Missouri, USA. His research program is focused on health and resilience processes in post-divorce families, particularly how adults support the healthy development of children across two residences through coparenting or conavigating health systems (e.g., hospitals, doctors' appointments), and how post-divorce and stepfamily relationships are developed, maintained, or dissolved. His recent publications include "Divorce and Childhood Chronic Illness: A Grounded Theory of Trust, Gender, and Third Party Care Providers” in Journal of Family Nursing (2016, with M. Coleman, L. Ganong, \& D. Gayer), "Perceived Barriers to Post-Divorce Coparenting: Differences Between Men and Women and Associations with Coparenting Behavior” in Family Relations (2016, with J. Beckmeyer, M. Coleman, \& L. Ganong,), and "Managing Chronic Conditions in College: Findings from Prompted Health Incidents Diaries” in Journal of American College Health (2017, with R. Ravert \& M. O’Guin).

Jonathon J. Beckmeyer, PhD, is an assistant professor in the department of Applied Health Science at the Indiana University School of Public Health-Bloomington, USA. His research program focuses on how family systems and intimate relationships act as determinants for adolescent and young adult health outcomes. His recent publications include "Experiences with Coparenting Scale: A Semantic Differential Measure of Post-Divorce Coparenting Satisfaction “ in Journal of Family Issues (2017, with L. Ganong, M. Coleman, \& M. Markham), "Perceptions of Alcohol Use by Friends Compared to Peers: Associations with Middle Adolescents' Own Use" in Substance Abuse (2016, with E. Weybright), and "Comparing the Associations between Three Forms of Adolescent Romantic Involvement and Their Engagement in Substance Use” in Journal of Adolescence (2015).

Chang Su-Russell, MA, is a doctoral candidate in Human Development and Family Science at the University of Missouri, USA. Her research program is focused on the influence of quality parenting and caregiving environments on children's socioemotional wellbeing and developmental competences across cultural and ethnoracial backgrounds. Her recent publications include "Analyzing Teacher Narratives in Early Childhood Garden-Based Education" in Journal of Environmental Education (2017, with C. Murakami, \& L. Manfra), and "The Interplay of Maternal Sensitivity and Toddler Engagement of Mother In Predicting Self-Regulation" in Developmental Psychology (2017 with J. Ispa, F. Palermo, \& G. Carlo). 


\begin{abstract}
Drawing on a social determinants of health framework, we evaluated associations between perceived family-centered care (FCC) and positive developmental outcomes for youth with special health care needs across six different family structures (married biological-families, cohabiting biological-families, married stepfamilies, cohabiting stepfamilies, divorced/separated single-mother families, and never married single-mother families). Using data from the 20112012 National Survey of Children’s Health, we found that married biological families perceive greater FCC than do other family structures. Perceived FCC was positively associated with all three positive youth outcomes evaluated (children's health, participation in extracurricular activities, and flourishing) in married biological families, and two of the three outcomes (children's health and flourishing) in married stepfamilies and divorced/separated single-mother families. Implications for health care provision and future research with structurally diverse families are discussed.
\end{abstract}

Acknowledgements: Data for this project comes from the Child and Adolescent Health Measurement Initiative (CAHI). National Survey of Children's Health 2011-2012 Indicator Data Set. Data Resource Center for Child and Adolescent Health. www.childhealthdata.org

Address all correspondence to: Luke Russell, PhD, Assistant Teaching Professor, Department of Human Development and Family Science, University of Missouri, 410 Gentry Hall, Columbia, MO; E-mail: russelllt@missouri.edu 
In 1960, 73\% of children under age 18 lived in families headed by their married biological parents. By 2015 that number had decreased to 46\%, with a plurality of children instead living in single-parent, divorced, cohabiting, or remarried households (Pew Research Center, 2015). This shift in prevalence of diverse family structures can present a challenge for doctors’ and nurses’ efforts to promote children’s health and well-being (Chen \& Escarce, 2008; Rusell, Coleman, Ganong, \& Gayer, 2016) particularly if children have a Special Health Care Need (SHCN). SHCNs reflect chronic physical, developmental, behavioral, or emotional conditions that require additional services beyond those provided to children in general (Bethell et al., 2011). Approximately 14.6 million children in the United States are estimated to have at least one SHCN (National Survey of Children’s Health, 2012), and providing care for such children accounts for over $40 \%$ of pediatric health care spending (Newacheck \& Kim, 2005). Family-centered care (FCC) occurs when health care professionals recognize and include family members as collaborators in the health care process, and is an important and relevant approach to support positive developmental and health outcomes for youth with SHCNs (Kuhlthau et al., 2011). Though a handful of qualitative investigations have suggested that family structural diversity may present challenges for health care delivery and provision to youth with SHCNs (e.g., Kelly \& Ganong, 2011; Russell et al., 2016) empirical evidence of differences in experiences and impacts of FCC across diverse family structures does not currently exist. In the present study, we drew on a social determinants of health framework (Viner et al., 2012) to better understand how family structure may affect parents’ perceptions of FCC and its associations with positive developmental outcomes for youth with SHCNs. Specifically, we tested the associations between parental perceptions of FCC and positive youth developmental outcomes in six different family structures: married biological-families, cohabiting biological- 
families, married stepfamilies, cohabiting stepfamilies, divorced/separated single-mother families, and never married single-mother families.

\section{Positive Developmental Outcomes in Youth}

In an effort to extend knowledge about the health and wellbeing of youth in structurally diverse families we sought to evaluate how perceptions of FCC was associated with three positive developmental outcomes among youth with SHCN: excellent child health, youth flourishing, and participation in extracurricular activities. Historically, research on youth in structurally diverse families has largely focused on adverse health outcomes (e.g., Ziol-Guest \& Dunifon, 2014), problem-behaviors (e.g., Lansford, Ceballo, Abbey, \& Stewart, 2001) and/or the deficits of structurally diverse families in comparison to families headed by two married parents (Ganong, Coleman, \& Russell, 2015). In order to help increase our knowledge about what is beneficial to youth, even in the context of potential risks, we instead drew on holistic models that emphasize adolescence as a period of opportunity to instill values and skills needed for positive developmental trajectories (Steinberg, 2014). Although several models of positive developmental outcomes have been developed (see Benson, Scales, \& Syvertsen, 2011; Bowers et al., 2010; Lerner, Lerner, \& Benson, 2011), they share several common elements including the importance of maintaining overall health, developing skills needed for personal or professional success, and participating in extracurricular activities. As enshrined in the World Health Organization (2007) constitution, the ability to obtain an excellent sense of physical, mental, and social well-being is widely regarded as a fundamental aspect of healthy child development. Developmental scientists have also suggested that the abilities to delay gratification, exercise self-control, understand and control emotions, and engage or persist with tasks are crucial in helping youth flourish in the face of challenging and novel experiences (Farley \& Kim-Spoon, 2014; Larson \& Rusk, 2011; 
Steinberg, 2014). Finally, extracurricular activities (i.e., organized activities outside of the school day) often operate as a primary context for positive youth development by providing youth with meaningful opportunities for knowledge and skill development that may not be included in the school day (Fredricks \& Simpkins, 2012; Vance, 2016), and the chance to form caring connections with friends and adult mentors (Mueller, Lewin-Bizan, \& Urban, 2011).

The presence of SHCNs may challenge youths’ abilities to achieve positive developmental outcomes. For example, functional limitations may hinder participation in extracurricular activities, thereby depriving them of potentially beneficial social or emotional experiences such activities can foster (Murphy, Carbone, \& The Council on Children with Disabilities, 2008). Additionally, managing youth with SHCNs' health care appointments and regimens is often highly demanding financially, emotionally, and logistically (Lutenbacher, Karp, Ajero, Howe, \& Williams, 2005). As a result, youth with SHCNs may have reduced access to extracurricular programs, opportunities to build self-regulation skills, or capability to maintain their health (Redquest, Reinders, Bryden, Schneider, \& Fletcher, 2015). To overcome the additional challenges introduced by SHCNs may require considerable coordination among physicians, parents, coaches, teachers, and school administrators (Murphy et al., 2008). That is, FCC provides one approach to integrating and coordinating care among youth with SHCNs across diverse family structures.

\section{Family-Centered Care}

The movement to increase FCC by health care personnel is based on the premise that mutually respectful, collaborative relationships with the family members of patients are critical to promoting individual, family, and community health (Committee on Hospital Care and Institute for Patient- and Family-Centered Care, 2012). FCC reflects an approach to health care 
decision making that incorporates five core principles: (1) The open, objective, and unbiased sharing of information between care providers and family members; (2) The development of a working relationship with family members that includes respect for cultural and care-related values and practices; (3) The inclusion and involvement of family members as partners in care; (4) A willingness to negotiate and change medical care plans with families when deemed appropriate; and (5) Consideration for the context of family, home, school, and the quality of life of patients and their families (Kuo, Bird, \& Tilford, 2011). Care for chronic conditions largely occurs in the home and by family members of pediatric patients. Thus, FCC may be particularly important in promoting health and well-being among children with SHCNs by providing adult caretakers opportunities to discuss their goals, concerns, and questions about children’s care (Denboba, McPherson, Keeney, Strickland, \& Newacheck, 2006; Kuo et al., 2011). Further, as children with SHCNs are expected to have more frequent and meaningful interactions with health care professionals than their peers who only see health care providers occasionally for routine treatment or acute illness, investigating the effects of FCC within this population seems pertinent (Kuhlthau et al., 2011; Kuo et al., 2011).

FCC may benefit youth and their families through several relational and social mechanisms. FCC may allow clinicians to communicate to parents that their child can engage in extracurricular activities, provide a forum to discuss challenges and propose solutions to cognitive and social impairments, and create an opportunity for youth and their parents to be heard and contribute to care decisions (Denoba et al., 2006). Additionally, open, trusting relationships between family members and health care providers are crucial to ensuring pediatric regimen adherence (Hanghøj \& Boisen, 2014; Russell et al., 2016). Previous research with children with SHCN has found that increased FCC can improve family's coordination with 
schools, leading to improved school attendance (Barnard-Brak, Stevens, \& Carpenter, 2017). Despite the anticipated benefits of FCC for youth with SHCNs, recent research has illustrated that medical health care professionals can find it difficult to implement FCC in diverse family structures (Russell et al., 2016). Therefore, parent and youth living in different family structures may have different experiences with FCC. A social determinants of health framework serves as a useful model for exploring such disparities.

\section{Family Structure as a Social Determinant of Health}

The World Health Organization (2010) social determinants of health (SDOH) framework seeks to evaluate how the economic, political, social, environmental, and cultural conditions in which people live affect their health and well-being. Often, this framework has been utilized to study health disparities and inequities that occur on the basis of socioeconomic position, social class, race/ethnicity, and gender within and across societies (Raphael, 2006; Viner et al., 2012). Although some SDOH models conceptualize family structure as an intermediate mechanism that may directly influence children’s health (e.g. Viner et al., 2012), family as a primary topic of investigation has been largely overlooked in previous SDOH research and family-related concepts and processes remain underdeveloped within this model (Deatrick, 2017). We contend family structure may instead operate in a similar manner to socioeconomic position, social class, race/ethnicity, gender, or other stigmatized minority statuses. That is, the poor health outcomes for children in diverse family structures may in part be a function of differential and inequitable access to resources and treatment resulting from membership in underprivileged social groupings (i.e., World Health Organization, 2010). Figure 1, used to guide our investigation, provides a conceptual model that displays this reconceptualization of family structure within the social determinants of health framework used by the World Health Organization. 
There is little debate that children in diverse family structures are at greater risk of experiencing unequal health outcomes as compared to their peers raised by married parents, explanations for these disparities, however, are more contested (Amato, 2010; Ganong et al., 2015). There are consistent empirical findings that living in diverse family structures (as compared to married biological families) is associated with poorer health outcomes (e.g., higher incidences of chronic illness) and reduced utilization of appropriate health care services (Blackwell, 2010; Chen \& Escarce, 2008; Scharte, Bolte, \& GME Study Group, 2013; Victorino \& Gauthier, 2009; Ziol-Guest \& Dunifon, 2014). Much previous comparative research has been (mis)used as evidence that diverse family structures may be inherently detrimental to children's health, or explained away as representative of pre-existing health deficits (Ganong et al., 2015). A reorganized SDOH framework, however, can be used as a guide to evaluate whether family structure may be linked in part to children's health outcomes through intermediate environmental, economic, and social experiences (Viner et al., 2012). One way to accomplish this would be to demonstrate that youths' developmental and health opportunities are constrained by their social environments, particularly if they belong to social groupings (in this case, diverse family structures) that lack prestige, power, or resources within society (Viner et al., 2012).

Evidence that disparities in children's health across family structures are consequences of societal inequities are increasingly prevalent. Access to monetary resources and social capital have been repeatedly identified as important mediators of children's mental and physical health differences across family structures (Barrett, \& Turner, 2005; Wen, 2008). That many divorcing or separating parents lack access to fair, expedient, and inexpensive court systems often exacerbates wealth inequalities that exist across diverse family structures (Emery, 2011; Henderson, 2003. Researchers have recently found evidence that children living in single-mother 
and single-father families are more likely to reside in neighborhoods with higher levels of pollution (Downey, Crowder, \& Kemp, 2017). There is also substantial evidence that divorced and single-parent families often face social stigma and rejection that may negatively impact their well-being, and which is indicative of their disadvantaged social status compared to a more idealized married two-parent household (Coleman, Ganong, \& Russell, 2013; Wrzus, Hänel, Wagner, \& Neyer, 2013). As medical technology has progressed it has become possible to demonstrate that stressful experiences like social exclusion create "wear and tear" on the human body over time due to physiological responses to perceived threats, concerns, or social rejections (Ganzel, Morris, \& Wethington, 2010; Juster, McEwen, \& Lupien, 2010). We contend that interactions with health care providers, and experiences of FCC, may operate as one additional such mechanism, helping to explain health disparities across family structures.

\section{Family-Centered Care and Family Structure}

Research on family-oriented health care models has overwhelmingly focused on married families (Brown et al., 2008; Phares, Lopez, Fields, Kamboukos, \& Duhig, 2005). As a result doctors and nurses may lack the resources, willingness, or awareness to provide effective FCC in the context of the specific challenges that can occur in diverse family systems. For example, it may be difficult to implement FCC when families have ongoing conflicts and disagreements, as can be common in post-divorce or non-residential families (Russell et al., 2016). Stigma regarding diverse family structures may also affect the implementation of FCC. Ganong and Coleman (1997) found that though nurses provided equal amounts of technical information to patients regardless of their marital status, they are less likely to provide affective support or information to recently divorced patients. Additionally, in stepfamilies, significant ambiguity often surrounds stepparents' roles as a care providers in health care situations. Stepparents may 
or may not be considered “immediate” family depending on the ranking health care personnel's definition (Ganong \& Coleman, 2017; Mason, Harrison-Jay, Savre, \& Wolfinger, 2002; Zarelli, 2009). Thus, stepparents may be more likely to be excluded from care, or provided with reduced attention or technical information from health care providers due to legal constraints or family tensions (Kelly \& Ganong, 2011; Mason et al., 2002; Zarelli, 2009). Structurally diverse families may also face challenges in accessing high quality pediatric health care due to a lack of economic resources or health insurance. Women in divorced or single-parent families are substantially more likely to report financial distress than their peers in first-marriage families (Malone, Stewart, Wilson, \& Korsching, 2010) and are also less likely to have consistent health insurance coverage (Karpman, Gates, Keeney, \& McMorrow, 2016). Both lower incomes and lack of health insurance are associated with parents feeling less like partners in their children’s care (Denboba et al., 2006). Family transitions such as divorce or remarriage may also bring with them residential transitions and changes in health care providers, which may further contribute to undermining the ability of such families to access effective FCC.

\section{Present Study}

The present study addressed a significant gap in the current health literature by conducting a secondary analysis of data provided by parents of youth with SHCNs who participated in the 2011-2012 National Survey of Children's Health (NSCH). First, we tested if family structure was associated with perceptions of FCC. Based on our SDOH model, we hypothesized that parents in biological-married families would perceive more FCC than those in other family structures. Second, following various calls for increased within family structure analyses (see Amato, 2010; Brown et al., 2008; Ganong, 2011) we tested the associations between FCC and three indicators of positive youth development (excellent physical health, 
youth flourishing, and participation in extracurricular activities) separately for youth with SHCN living in each family structure. We hypothesized that perceptions of FCC would be positively associated with all three indicators of positive youth development outcomes in all family structures. We also hypothesized that differences in perceived social status and familiarity with diverse family structures would affect the strength of the association between perceptions of FCC and the indicators of positive youth development.

\section{Methods}

\section{Participants}

To conduct our analyses, data were drawn from the 2011-2012 NSCH, a cross-sectional nationally representative survey of households in the United States, with at least one child between 0-17 years old. In each selected household, a target child was chosen at random to be the focus of survey. Then a parent in each household completed the survey with regards to the focus child. For this study we limited the overall NSCH sample to households with a) focus children between 12-17 years old that had at least one SHCN, b) either a biological-married, biological cohabiting, married step-, cohabiting step-, divorced/separated single-mother, or never married single-mother family, and c) complete data on the variables used in this study. Target children were determined to have a SHCN if parents reported that a doctor or health care provider had told them the study child had any of a list of 18 chronic health conditions. The final sample was comprised of 8740 parents (see Table 1 for demographics for each family structure). Because of our secondary use of a blinded public-use data-set, this research was approved as non-human subjects research by the Indiana University Institutional Review Board.

[insert Table 1 about here]

\section{Measures}


The National Survey of Children’s Health was developed by a technical expert panel consisting of state and federal Maternal and Child Health Bureau program directors, representatives of family organizations, child health services researchers, and survey design experts (Data Resource Center for Child and Adolescent Health, 2013). All items were selected based on the technical expert panel's own expertise and reviews of other national surveys like the National Health Interview Survey, the National Survey of Children with Special Health Care Needs, the Consumer Assessment of Health Plans Survey, The National Survey of America’s Families, and the Youth Risk Behavior Survey in order to permit comparisons and reduce the need for extensive pretesting (Data Resource Center for Child and Adolescent Health, 2013). In the following sections, we outline exactly which items and measures were used in our analyses.

Family-centered care. FCC was measured with 5-items $(\alpha=.84)$, regarding experiences with health care providers during the past 12 months. The 5 items included: "How often did [child's name]'s doctors and other health care providers spend enough time with (him/her)”, “How often did [child’s name]'s doctors and other health care providers listen carefully to you?”, “When [child’s name] is seen by doctors and other health care providers, how often are they sensitive to your family’s values and customs?”, "How often did you get the specific information you needed from [child's name]'s doctors and other health care providers” and "How often did [child's name]'s doctors or other health care providers help you feel like a partner in [his/her] care?” Each item was rated on a 4-point scale ( 1 = never to 4 = always). Scores were computed by averaging across the items; higher scores reflected parents experiencing greater FCC.

Positive developmental outcomes. Positive developmental outcomes were assessed as flourishing, participation in extracurricular activities, and excellent physical health. Flourishing was measured with 5-items ( $\alpha=.78$ ) that reflected youths’ abilities to achieve positive 
interpersonal experiences and self-regulation skills (e.g., "[He/she] finishes the tasks [he/she] starts and follows through with what [he/she] says [he'll/she’ll] do.” and “[He/she] shows interests and curiosity in learning new thing”). Each item was rated on a 5-point scale (1 = never to 5 = always). Flourishing scores were computed by averaging across the items; higher scores reflected greater flourishing. Participation in extracurricular activities was measured with 3items that asked if (yes or no) in the past 12 months the target child had a) played on a sports team, b) participate in any clubs or organizations, and c) been involved in any type of community service. Extracurricular activities scores computed by summing the items; higher scores reflected participating in more activities. Excellent physical health was measured with 1-item: "In general, how would you describe [Study Child]’s health?” There were five response options: excellent, very good, good, fair, and poor. As responses were skewed towards excellent health we dichotomized the variable into $1=$ excellent and $0=$ very good, good, fair, or poor.

Control variables. In line with the SDOH framework guiding our study, and based on previous research, we included five demographic control variables: child gender (male or female), child age in years, child race/ethnicity (white non-Hispanic, Black non-Hispanic, Hispanic, and Other), maternal education (less than high school, high school graduate, greater than high school), and poverty level based on eight categories ranging from at or below 100\% poverty level to above $400 \%$ poverty level. We also controlled for three health characteristics in an effort to control for variability in illness severity: total number of SHCNs (range 1 to 18), presence of an individualized education program (IEP; yes or no) and if the target child had any unmet health care needs (yes or no). Finally, based on substantial existing evidence that parental knowledge and parent-child relationship quality are associated with child adjustment (Duncan, Coatsworth, \& Greenberg, 2009; Lippold, Greenberg, \& Collins, 2013), we controlled for two 
aspects of the parent-youth relationship: parent knows child's friends based on an item asking parents how many of the focus child's friends they have met ( $1=$ knows none of their friends to 4 = knows all of their friends) and parent-youth closeness based on an item that asked parents how well they and the target child are able to talk about things that really matter $(1=$ not well at all to $4=$ very well).

\section{Analysis Plan}

We first used ANVOA models to determine if perceptions of FCC, youth flourishing, and participating in extracurricular activities differed based on family structure. We used a chi-square test to determine if family structure was associated with youths’ physical health being excellent. Then we used multiple regression to test if family-centered care was associated with youth flourishing or participating in extracurricular activities and used logistic regression to test if family-centered care was associated youth having excellent physical health. We computed separate regression models for each outcome for each family structure. An a priori calculation using the G*Power 3 calculator developed by Faul, Erdfelder, Lang, and Buchner (2007) suggested that in order to detect a medium effect size $\left(f^{2}=.15\right)$ with limited probabilities for type I or type II errors ( $\alpha=.05 ; 1-\beta$ [power] $=.80$ respectively) in our regression models would require an estimated sample size of 131 participants. The least prevalent family structure in our actual analyses (Cohabiting Biological Families) had reports from 135 individuals, suggesting we had adequate power to detect meaningful effects in each analysis.

\section{Results}

\section{Family Structure Differences in Perceptions of Family-Centered Care and Positive Developmental Outcomes}


Results from the family structure difference tests are presented in Table 2. Perceptions of FCC differed between family structures, $F(5,8734)=24.58, p<.001$. Parents in married biological families perceived greater FCC than those in the other five family structures, which did not differ from each other. Youth flourishing also differed between family structures, F(5, 8734) $=46.59, p<.001$. Youth flourishing was higher in married biological families than in the other family structures, which did not differ from each other. Participation in extracurricular activities also differed between family structures, $F(5,8734)=100.57, p<.001$. Youth in married biological families participated in more extracurricular activities than youth in the other five family structures. Youth in married stepfamilies also participated in more extracurricular activities than those in cohabitating biological families and both types of single-mother families. Finally, family structure was associated with excellent youth physical health, $\chi^{2}(5)=145.48, p<$ .001. Married biological families had the higher proportion of youth with excellent physical health and never married single-mother families had the lowest.

[insert Table 2 about here]

\section{Youth Flourishing}

Results for the regression models testing if perceptions of FCC were associated with youth flourishing are presented in Tables 3 and 4. Perceptions of FCC were significantly associated with youth flourishing in married biological families, $\beta=.10, p<.001$, married stepfamilies, $\beta=.10, p<.001$, and divorced/separated single-mother families, $\beta=.13, p<.001$. Thus in these families, perceiving more FCC was associated with greater youth flourishing. Perceptions of FCC were not associated with youth flourishing in cohabiting biological families, $\beta=.05, p=.578$, cohabiting stepfamilies, $\beta=.10, p=.133$, or never married single-mother families, $\beta=.04, p=.338$. 
(Tables 3 and 4 about here)

\section{Participation in Extracurricular Activities}

Results for the regression models testing if perceptions of FCC were associated with participation in extracurricular activities are presented in Tables 5 and 6. Perceptions of FCC were significantly associated with participation in extracurricular activities in married biological parent families, $\beta=.03, p=.029$. For youth living with married biological parents, perceptions of FCC were associated with having participated in more extracurricular activities. Perceptions of FCC were not associated with participation in extracurricular activities in married stepfamilies, $\beta=.06, p=.069$, divorced/separated single-mother families, $\beta=.01, p=.584$, cohabiting biological families, $\beta=.16, p=.060$, cohabiting stepfamilies, $\beta=-.11, p=.115$, or never married single-mother, $\beta=-.01, p=.812$.

[insert Tables 5 and 6 about here]

\section{Excellent Physical Health}

Results for the logistic regression models testing if perceptions of FCC were associated with youths’ physical health are presented in Tables 7 and 8. Perceptions of FCC were significantly associated with parents perceiving youths' health as excellent in married biological families, $O R=1.62, p<.001$, married stepfamilies, $O R=1.49, p=.01$, and divorced $/$ separated single-mother families, $O R=1.28, p=.009$. In each of these family structures, perceiving greater FCC is associated with being more likely to report that youths’ physical health was excellent. Perceptions of FCC were not associated with youth physical health in cohabiting biological families, $O R=1.30, p=.417$, cohabiting stepfamilies, $O R=1.50, p=.129$, or never married single-mother families, $O R=0.98, p=.868$.

[insert Tables 7 and 8 about here] 


\section{Discussion}

Our results suggest that youth with SHCN in diverse family structures have different perceptions of FCC, and variable developmental outcomes. Analyses supported our first hypothesis that married biological parents would perceive greater FCC than do parents in other family structures. Regarding our second hypothesis, however, perceptions of FCC were related to positive youth developmental outcomes in select family structures and domains. In line with our expectation that the association between perceptions of FCC and youth developmental outcomes would be the strongest in married biological families, we found such families to be the only family structure in which perceptions of FCC was associated with all three positive youth development outcomes included in our analyses. We also found evidence that perceptions of FCC benefitted youth flourishing and physical health in married stepfamilies and divorced/separated single-mother families. These results support the notion that continuing to implement FCC in health settings can be valuable for improving youth with SHCN's health and positive development, despite the difficulties health care providers may face in doing so, for some of the most common family structures (Foster, Whitehead, \& Maybee, 2016; Kuo et al., 2011). No such relationship existed between perceptions of FCC and positive developmental outcomes, however, in cohabiting biological, cohabiting step- or never married single-mother families.

Drawing on the SDOH framework that guided our investigation, we believe our null findings carry as much importance as the significant findings. It is crucial to understand why perceptions of FCC do not appear to benefit positive youth outcomes in cohabiting biological families, cohabiting stepfamilies, and never married single-mother families. As the presence of a current or previous marriage differentiated the families and youth that appear to benefit from 
perceptions of FCC from those that did not, perhaps marriage continues to retain a privileged position within U.S. society and health care systems (Coontz, 2000; Walker, 2009). This would in-part explain differential treatment or attitudes by health care professionals directed towards children and adults in structurally diverse families (Ganong \& Coleman, 1997; Zarelli, 2009). We speculate that marriage may be used by nurses and doctors as the primary mechanism for identifying "family members" and making determinations about whether they should invest time in “other” caregivers. Among unmarried couples, stricter boundaries among family members may mean there are care providers (e.g., parent's cohabiting or non-cohabiting romantic partners or extended family members and friends) who provide significant care or supervision of youth, but whom may be excluded from health care appointments (and unrepresented in surveys completed solely by a primary caregiver). Unmarried caretakers may be perceived as less committed or invested in children's care (Lundberg, \& Pollak, 2015), and so may not receive the attention from health care providers that married (or previously married) parents would. Health care personnel may consider such a designation reasonable given legal preferences for marital and blood ties (Jacobs, 2007), and federal policies that limit the sharing of health information beyond such ties (e.g. the Health Insurance Portability and Accountability Act of 1996), but it may also be costly to the health and flourishing of youth living in diverse family structures.

An alternative explanation for our pattern of findings could be that youth with SHCN in non-marital family structures have other characteristics or family dynamics that suppress or overpower any potential benefits of FCC. In our analyses, we controlled for several other common social groupings within the social determinants of health model (e.g. gender, race/ethnicity, socioeconomic position), aspects of illness severity, and the quality of the parentchild relationship (WHO, 2010). Our results showed that across various family structures these 
indicators were often important predictors of several of the positive developmental outcomes we investigated. Previous research on youth with SHCN have found that children with increased medical complexity, who belong to minority racial or ethnic groups, who experience multiple family transitions; and who are economically vulnerable, are at substantially increased risks for having unmet health care needs and challenges with schooling (Amato, 2010; Bethell et al., 2012, 2014; Brown, Green, Desai, Weitzman, \& Rosenthal, 2014; Kuo et al., 2014). It is possible that these other "risk factors", which were in some instances more prevalent in cohabiting biological families, cohabiting stepfamilies, and never-married single mother families, may result in FCC having little discernable effect in impacting children's positive developmental outcomes. Regardless, we would still propose that this may be evidence for the need to adapt family-centered care for such families if health care practitioners seek to promote the positive development and wellbeing of their patients.

\section{Implications for Practitioners}

Our results suggest that FCC can be beneficial for improving the health and positive development of many youth with SHCN, but is not, as currently practiced, a universal elixir. Bell (2013) contended that too often FCC has been operationalized and implemented through familyfriendly visiting hours, reducing redundancy and waiting times for families, and a predominant focus on quick fixes to institutional policies and procedures. She asserted that despite the familyfriendly rhetoric used, most FCC does not focus on building relationships with families (rather than a single care provider) or providing truly family-based interventions. As a result, despite health care practitioners increased efforts, family members may fail to recognize practices like extended visiting times or longer clinic hours as truly reflecting family-centered care. The presence of several nonsignificant effects in our results, and our finding that there were reduced 
perceptions of FCC in structurally diverse families, may reflect the need to broaden FCC training to better address the variability that exists in contemporary American families.

Family nurses are well-positioned to lead these adjustments, by recognizing the need to reach out to the entire family, not just a primary caretaker. Inviting secondary and tertiary caretakers to family conferences, who may live in a child's household only part-time, or even in an entirely separate household, may be critical to ensuring a child is receiving the care and responsiveness they need (Russell et al., 2016). Family nursing tools like the 15-minute family interview (Wright \& Leahey, 2013), nurse-family meetings (Nelms \& Eggenberger, 2010), or genograms and ecomaps that can be used to build and recognize family capacity and resources could be especially valuable in working with structurally diverse families (Rempel, Neufeld, \& Kushner, 2007).

Our results also demonstrate the importance of building relationships within families, and particularly, between parents and children, as holding important implications for the health and wellbeing of children with SHCN. Across most of our models, parent-youth closeness, and parental knowledge of youth peers were significantly associated with positive youth outcomes. Simple interventions, such as encouraging parents to engage in “mindful parenting” by asking youth about their friends and listening compassionately, may lead to improved parent-child relationships, parental knowledge, and ultimately more positive youth adjustment (Duncan et al., 2009; Lippold et al., 2013).

\section{Limitations}

It is important to understand the findings of this study within the context of its limitations. One important limitation is the cross-sectional nature of the data. As a result, we cannot determine if FCC leads to changes in positive developmental outcomes, or if positive 
developmental outcomes lead to more FCC. Perhaps, it is easier for doctors and nurses to engage in FCC when youth already demonstrate positive well-being. It also means we could only account for family structure at a single point in time, whereas accounting for stability and instability in family structure, or other aspects of family dynamics (e.g. levels of conflict or communication among parents) may have provided further insight and explanatory power to our statistical models (Amato, 2010).

A second limitation is that data in the National Survey of Children's Health are reported by a single informant. It is possible that health care professionals or other family members could perceive FCC quite differently. The items used to evaluate FCC in this analysis rely on a target parent self-reporting their experiences of being included and treated respectfully by a care provider. As noted previously, this may result in other important caregivers (e.g. romantic partners, extended family and friends) being less or unrepresented by the primary caretaker’s responses. Measurement non-equivalence across family structures could also be a potential concern. Researchers often utilize measures of family processes and functioning that were developed and psychometrically validated primarily with white, middle-class, married families (Henrich, Heine, \& Norenzayan, 2010). It cannot be taken for granted, however, that such measures can be equivalently interpreted in the context of various racial, cultural, socioeconomic, and family structure contexts (Henrich et al., 2010).

Third, it is important to recognize we did not have equal samples of each family structure within our analyses. It should be noted that cohabiting biological families, cohabiting stepfamilies, and never married single-mother families were the three least prevalent family structures in our study. Having fewer participants in these family types makes it less likely to detect significant associations than in the family structures with more participants (i.e., married 
biological families, married stepfamilies, and divorced/separated single-mother families). That noted, our a priori calculations indicated our samples of each family structure were sufficient for detecting meaningful effects. Furthermore, given that conducting research on less populous family structures is a common challenge for both family and health research (Brown et al., 2008; Ganong, 2011) we believe our findings represent an important contribution to the literature.

Finally, we were unable to completely control for illness severity within our sample. Though there is little evidence that a child's illness diagnosis greatly increases the likelihood of parental divorce, there is evidence that children's chronic conditions (and the severity of that condition) may add additional stressors to marriages (for a review see Brown et al., 2008) which could in turn impact youth flourishing and well-being. The nature of the secondary data analyses we conducted unfortunately did not allow us to test for such reciprocal or confounding effects. Future research should address these shortcomings by using longitudinal methods that follow individuals over time, collecting data from multiple reporters, and making use of contextuallysensitive measures that can account for family background or illness severity. Future research may also benefit by incorporating additional information about the context in which families are experiencing FCC (e.g., how many health care providers are they interacting with, frequency of health care visits, parental work-schedules, and distance to health care providers). Such contextual variables may interact with family structure related barriers to shape parents' and youths’ experiences of FCC.

\section{Conclusion}

With the increasing prevalence of diverse family structures, understanding how to provide effective FCC should be an important priority for health care and family professionals. This study provides additional evidence that further attempts to actively include family members 
as valuable collaborators and partners in the care of youth with special health care needs can be beneficial not only for youth with SHCN's health but also other aspects of positive development. That these benefits are not universal across family structures, however, remains concerning. Future work should look to address these shortcomings and help support caretakers and children in contemporary families.

\section{Declaration of Conflicting Interests}

The authors declared no potential conflicts of interest with respect to the research, authorship, and/or publication of this article.

\section{Funding}

The authors received no financial support for the research, authorship, and/or publication of this article. 


\section{References}

Amato, P. R. (2010). Research on divorce: Continuing trends and new developments. Journal of Marriage and Family, 72, 650-666. doi:10.1111/j.1741-3737.2010.00723.x

Barnard-Brak, L., Stevens, T., \& Carpenter, J. (2017). Care coordination with schools: The role of family-centered care for children with special health care needs. Maternal and Child Health Journal, 21, 1073-1078. doi:10.1007/s10995-016-2203-X

Barrett, A. E., \& Turner, R. J. (2005). Family structure and mental health: The mediating effects of socioeconomic status, family process, and social stress. Journal of Health and Social Behavior, 46, 156-169. doi:10.1177/002214650504600203

Bell, J. M. (2013). Family nursing is more than family centered care [Editorial]. Journal of Family Nursing, 19, 411-417. doi:10.1177/1074840713512750

Benson, P. L., Scales, P. C., \& Syvertsen, A. K. (2011). The contribution of the developmental assets framework to positive youth development theory and practice. Advances in Child Development and Behavior, 41, 197-230. doi:10.1016/B978-0-12-386492-5.00008-7

Bethell, C. D., Forrest, C. B., Stumbo, S. Gombojav, N., Carle, A., \& Irwin, C. E. (2012).

Factors promoting or potentially impeding school success: Disparities and state variations for children with special health care needs. Maternal and Child Health Journal, 16, S35S43. doi:10.1007/s10995-012-0993-z

Bethell, C. D., Kogan, M. D., Strickland, B. B., Schor, E. L., Robertson, J., \& Newacheck, P. W. (2011). A national and state profile of leading health problems and health care quality for US children: Key insurance disparities and across-state variations. Academic Pediatrics, 11, S22-S33. doi:10.1016/j.acap.2010.08.011 
Bethell, C. D., Newacheck, P. W., Fine, A., Strickland, B. B., Antonelli, R. C., Wilhelm, C.,... Wells, N. (2014). Optimizing health and health care systems for children with special health care needs using the life course perspective. Maternal and Child Health Journal, 18, 467-477. doi:10.1007/s10995-013-1371-1

Blackwell, D. L. (2010). Family structure and children's health in the United States: Findings from the National Health Interview Survey, 2001-2007. Vital and Health Statistics, 10, 1166. Washington, DC: National Center for Health Statistics. Retrieved from https://www.cdc.gov/nchs/data/series/sr_10/sr10_246.pdf

Bowers, E. P., Li, Y., Kiely, M. K., Brittian, A., Lerner, J. V., \& Lerner, R. M. (2010). The five Cs model of positive youth development: A longitudinal analysis of confirmatory factor structure and measurement invariance. Journal of Youth and Adolescence, 39, 720-735. doi:10.1007/s10964-010-9530-9

Brown, N. M., Green, J. C., Desai, M. M., Weitzman, C. C., \& Rosenthal, M. S. (2014). Need and unmet need for care coordination among children with mental health conditions. Pediatrics, 133, e530-e537. doi:10.1542/peds.2013-2590

Brown, R. T., Wiener, L., Kupst, M. J., Brennan, T., Behrman, R., Compas, B. E,...Zeltzer, L. (2008). Single parents of children with chronic illness: An understudied phenomenon. Journal of Pediatric Psychology, 33, 408-421. doi:10.1093/jpepsy/jsm079

Chen A.Y., \& Escarce J. J. (2008). Family structure and the treatment of childhood asthma. Medical Care, 46, 174-184. doi:10.1097/MLR.0b013e318156ff20

Coleman, M., Ganong, L., \& Russell, L. T. (2013). Resilience in stepfamilies. In D. S. Becvar (Ed)., The handbook of family resilience (pp. 85-103). New York, NY: Springer. 
Committee on Hospital Care and Institute for Patient- and Family-Centered Care (2012). Patientand family-centered care and the pediatrician’s role. Pediatrics, 129, 394-404. doi:10.1542/peds.2011-3084

Coontz, S. (2000). Historical perspectives on family studies. Journal of Marriage and Family, 62, 283-297. doi:10.1111/j.1741-3737.2000.00283.x

Data Resource Center for Child and Adolescent Health (2013). 2011-2012 NSCH: Child health indicator and subgroups SPSS codebook, version 1.0. Baltimore, MD: Data Resource Center for Child and Adolescent Health. Retrieved from: https://childhealthdata.org/docs/nsch-docs/spsscodebook_2011_2012_nsch_v1_all.pdf?sfvrsn=6

Deatrick, J. A. (2017). Where is "family" in the social determinants of health? Implications for family nursing practice, research, education, and policy [Guest Editorial]. Journal of Family Nursing, Advance online publication. doi: $10.1177 / 1074840717735287$

Denboba, D., McPherson, M. G., Kenney, M. K., Strickland, B., \& Newacheck, P. W. (2006). Achieving family and provider partnerships for children with special health care needs. Pediatrics, 188, 1607-1615. doi:10.1542/peds.2006-0383

Downey, L., Crowder, K., \& Kemp, R. J. (2017). Family structure, residential mobility, and environmental inequality. Journal of Marriage and Family, 79, 535-555. doi:10.111/jomf.12355

Duncan, L. G., Coatsworth, J. D., \& Greenberg, M. T. (2009). A model of mindful parenting: Implications for parent-child relationships and prevention research. Clinical Child and Family Psychology Review, 12, 255-270. doi:10.1007/s10567-009-0046-3 
Emery, R. E. (2011). Renegotiating family relationships: Divorce, child custody, and mediation. ( $2^{\text {nd }}$ ed.). New York, NY: Guilford.

Faul, F., Erdfelder, E., Lang, A.-G., \& Buchner, A. (2007). G*Power 3: A flexible statistical power analysis program for the social, behavioral, and biomedical sciences. Behavior Research Methods, 39, 175-191. doi:10.3758/BF03193146

Farley, J. P., \& Kim-Spoon J. (2014). The development of adolescent self-regulation: Reviewing the role of parent, peer, friend, and romantic relationships. Journal of Adolescence, 37, 433-440. doi:10.1016/j.adolescence.2014.03.009

Fredricks, J. A., \& Simpkins, S. D. (2012). Promoting positive youth development through organized after-school activities: Taking a closer look at participation of ethnic minority youth. Child Development Perspectives, 6, 208-287. doi:10.1111/j.17508606.2011.00206.x

Foster, M., Whitehead, L., \& Maybee, P. (2016). The parents', hospitalized child's, and health care providers' perceptions and experiences of family-centered care within a pediatric critical care setting: A synthesis of quantitative research. Journal of Family Nursing, 22, 6-73. doi:10.1177/1074840715618193

Ganong, L. (2011). Return of the "intimate outsider”: Current trends and issues in family nursing research revisited. Journal of Family Nursing, 17, 416-440.

doi:10.1177/1074840711425029

Ganong, L. H., \& Coleman, M. (1997). Effects of family structure information on nurses’ impression formation and verbal responses. Research in Nursing \& Health, 20, 139-151. doi:10.1002/(SICI)1098-240X(199704)20:2<139::AID-NUR6>3.0.CO;2-L 
Ganong, L. H., \& Coleman, M. (2017). Stepfamily relationships: Development, dynamics, and interventions ( $2^{\text {nd }}$ ed.). New York, NY: Springer.

Ganzel, B. L., Morris, P. A., \& Wethington, E. (2010). Allostasis and the human brain: Integrating models of stress from the social and life sciences. Psychological Review, 117, 134-174. doi:10.1037/a0017773

Ganong, L., Coleman, M., \& Russell, L. T. (2015). Children in diverse families. In M. H. Bornstein and T. Leventhal (Eds.), Handbook of child psychology and developmental science Volume 4: Ecological settings and processes in developmental systems (pp. 133174). Hoboken, NJ: Wiley.

Hanghøj, S., \& Boisen, K. A. (2014). Self-reported barriers to medication adherence among chronically ill adolescents: A systematic review. Journal of Adolescent Health, 54, 121138. doi:10.1016/j.jadohealth.2013.08.009

Henderson, A. C. (2003). Meaningful access to the courts? Assessing self-represented litigants’ ability to obtain a fair, inexpensive divorce in Missouri’s court system. UMKC Law Review, 72, 571-591.

Henrich, J., Heine, S. J. \& Norenzayan, A. (2010). The weirdest people in the world? Behavioral and Brain Sciences, doi:10.1017/S0140525X0999152X

Jacobs, M. B. (2007). Why just two? Disaggregating traditional parental rights and responsibilities to recognize multiple parents. Journal of Law \& Family Studies, 9, 309340.

Juster, R., McEwen, B. S., \& Lupien, S. J. (2010). Allostatic load biomarkers of chronic stress and impact on health and cognition. Neuroscience \& Biobehavioral Reviews, 35, 2-16. doi:10.1016/j.neubiorev.2009.10.002 
Karpman, M., Gates, J. A., Keeney, G. M., \& McMorrow, S. (2016). How are moms faring under the Affordable Care Act? Evidence through 2014. Washington, DC: Urban Institute.

Kelly, K. P., \& Ganong, L. (2011). Moving to place: Childhood cancer treatment decision making in single-parent and repartnered family structures. Qualitative Health Research, 21, 349-364. doi:10.1177/1049732310385823

Kuhlthau, K. A., Bloom, S., Van Cleave, J., Knapp, A. A., Romm, D., Klatka, K.,...Perrin, J. M. (2011). Evidence for family-centered care for children with special health care needs: A systematic review. Academic Pediatrics, 11, 136-143. doi:10.1016/j.acap.2010.12.014

Kuo, D. Z., Bird. T. M., \& Tilford, J. M. (2011). Associations of family-centered care with health care outcomes for children with special health care needs. Maternal and Child Health Journal, 15, 794-805. doi:10.1007/s10995-010-0648-x

Kuo, D. Z., Goudie, A., Cohen, E., Houtrow, A., Agrawal, R., Carle, A. C., \& Wells, N. (2014). Inequities in health care needs for children with medical complexity. Health Affairs, 33, 2190-2198. doi:10.1377/hlthaff.2014.0273

Lansford, J. E., Ceballo, R., Abbey, A., \& Stewart, A. J. (2001). Does family structure matter? A comparison of adoptive, two-parent biological, single-mother, stepfather, and stepmother households. Journal of Marriage and Family, 63, 840-851. doi:10.1111/j.17413737.2001.00840.x

Larson, R. W., \& Rusk, N. (2011). Intrinsic motivation and positive development. Advances in Child Development and Behavior, 41, 89-130. 
Lerner, R. M., Lerner, J. V., \& Benson, J. B. (2011). Positive youth development: Research and applications for promoting thriving in adolescence. Advances in Child Development and Behavior, 41, 1-17. doi:10.1016/B978-0-12-386492-5.00001-4

Lippold, M. A., Greenberg, M. T., \& Collins, L. M. (2013). Parental knowledge and youth risky behavior: A person oriented approach. Journal of Youth and Adolescence, 42, 1732-1744. doi:10.1007/s10964-012-9893-1

Lundberg, S., \& Pollak, R. A. (2015). The evolving role of marriage: 1950-2010. The Future of Children, 25, 29-50. doi:10.1353/foc.2015.0011

Lutenbacher, M., Karp, S., Ajero, G., Howe, D., \& Williams, M. (2005). Crossing community sectors: Challenges faced by families of children with special health care needs. Journal of Family Nursing, 11, 162-182. doi:10.1177/1074840705276132

Malone, K., Stewart, S. D., Wilson, J., \& Korsching, P. F. (2010). Perceptions of financial wellbeing among American women in diverse families. Journal of Family and Economic Issues, 31, 63-81. doi:10.1007/s10834-009-9176-5

Mason, M. A., Harrison-Jay, S. H., Savre, G. M., \& Wolfinger, N. H. (2002). Stepparents: De facto parents or legal strangers? Journal of Family Issues, 23, 507-522. doi:10.1177/0192513X02023004003

Mueller, M. K., Lewin-Bizan, S., \& Urban J. B. (2011). Youth activity involvement and positive youth development. Advances in Child Development and Behavior, 41, 231-249. doi:10.1016/B978-0-12-386492-5.00009-9

Murphy, N. A., Carbone, P. S., \& The Council on Children with Disabilities. (2008). Promoting the participation of children with disabilities in sports, recreation, and physical activities. Pediatrics, 121, 1057-1062. doi:10.1542/peds.2008-0566 
National Survey of Children's Health. (2012). Data query from the Child and Adolescent Health Measurement Initiative. Baltimore, MD: Data Resource Center for Child and Adolescent Health. Retrieved from: http://childhealthdata.org/browse/survey/results?q=2546\&r=1

Nelms, T. P., \& Eggenberger, S. K. (2010). The essence of the family critical illness experience and nurse-family meetings. Journal of Family Nursing, 16, 462-486. doi:10.1177/1074840710386608

Newacheck, P. W., \& Kim, S. E. (2005). A national profile of health care utilization and expenditures for children with special health care needs. Archives of Pediatrics and Adolescent Medicine, 159, 10-17. doi:10.1001/archpedi.159.1.10

Pew Research Center (2015). Parenting in America. Washington, DC: Pew Research Center Social \& Demographic Trends. Retrieved from: http://www.pewsocialtrends.org/2015/12/17/1-the-american-family-today/

Phares, V., Lopez, E., Fields, S., Kamboukos, D., \& Duhig, A. M. (2005). Are fathers involved in pediatric psychology research and treatment? Journal of Pediatric Psychology, 30, 631-643. doi:10.1093/jpepsy/jsi050

Raphael, D. (2006). Social determinants of health: Present status, unanswered questions, and future directions. International Journal of Health Services, 651-677. doi:10.2190/3MW4DGRQ-2CRF

Redquest, B. K., Reinders, N., Bryden, P. J., Schneider, M., \& Fletcher, P. C. (2015). Raising a child with special needs: The perspective of caregivers. Clinical Nurse Specialist, 29, e8e15. doi:10.1097/nur.0000000000000122 
Rempel, G. R., Neufeld, A., \& Kushner, K. E. (2007). Interactive use of genograms and ecomaps in family caregiving research. Journal of Family Nursing, 4, 403-419. doi:10.1177/1074840707307917

Scharte, M., Bolte, G., \& GME Study Group. (2013). Increased health risks of children with single mothers: The impact of socio-economic and environmental factors. European Journal of Public Health, 23, 469-475. doi:10.1093/eurpub/cks062

Russell, L. T., Coleman, M., Ganong, L., \& Gayer, D. (2016). Divorce and childhood chronic illness: A grounded theory of trust, gender, and third party care providers. Journal of Family Nursing. 22, 252-278. doi:10.1177/1074840716639909

Steinberg, L. (2014). Age of opportunity: Lessons from the new science of adolescence. Boston, MA: Mariner Books.

Vance, F. (2016). Understanding adolescents' skill-building in the after-school context. Youth \& Society. Advance online publication. doi:10.1177/0044118x16649620

Victorino, C. C., \& Gauthier, A. H. (2009). The social determinants of child health: Variations across health outcomes - a population-based cross-sectional analysis. BMC Pediatrics, 9, 53-65. doi:10.1186/1471-2431-9-53

Viner, R. M., Ozer, E. M., Denny, S., Marmot, M., Resnick, M., Fatsui, A., \& Currie, C. (2012). Adolescence and the social determinants of health. The Lancet, 379, 1641-1652. doi:10.1016/S0140-6736(12)60149-4

Walker, A. J. (2009). A feminist critique of family studies. In S. A. Lloyd, A. L. Few, \& K. R. Allen (Eds.), Handbook of feminist studies (pp. 18-27). Thousand Oaks, CA: SAGE. 
Wen, M. (2008). Family structure and children's health and behavior: Data from the 1999 National Survey of America’s Families. Journal of Family Issues, 29, 1492-1519. doi:10.1177/0192513X08320188

World Health Organization (2007). Constitution of the World Health Organization: Basic documents (46 ${ }^{\text {th }}$ ed.). Geneva, Switzerland: World Health Organization.

World Health Organization (2010). A conceptual framework for action on the social determinants of health. Geneva, Switzerland: World Health Organization. Retrieved from http://www.who.int/sdhconference/resources/ConceptualframeworkforactiononSDH_eng. pdf

Wright, L. M., \& Leahey, M. (2013). Nurses and families: A guide to family assessment and intervention (6 $6^{\text {th }}$ ed.). Philadelphia, PA: F.A. Davis.

Wrzus, C., Hänel, M., Wagner, J., \& Neyer, F. J. (2013). Social network changes and life events across the life span: A meta-analysis. Psychological Bulletin, 139, 53-80. doi:10.1037/a0028601

Zarelli, D.A. (2009). Role-governed behaviors of stepfathers in families with a child with chronic illness. Journal of Pediatric Nursing, 24, 90-100. doi:10.1016/j.pedn.2008.02.029

Ziol-Guest, K. M., \& Dunifon, R. E. (2014). Complex living arrangements and child health: Examining family structure linkages with children’s health outcomes. Family Relations, 63, 424-437. doi:10.1111/fare.12071 
Figure 1.

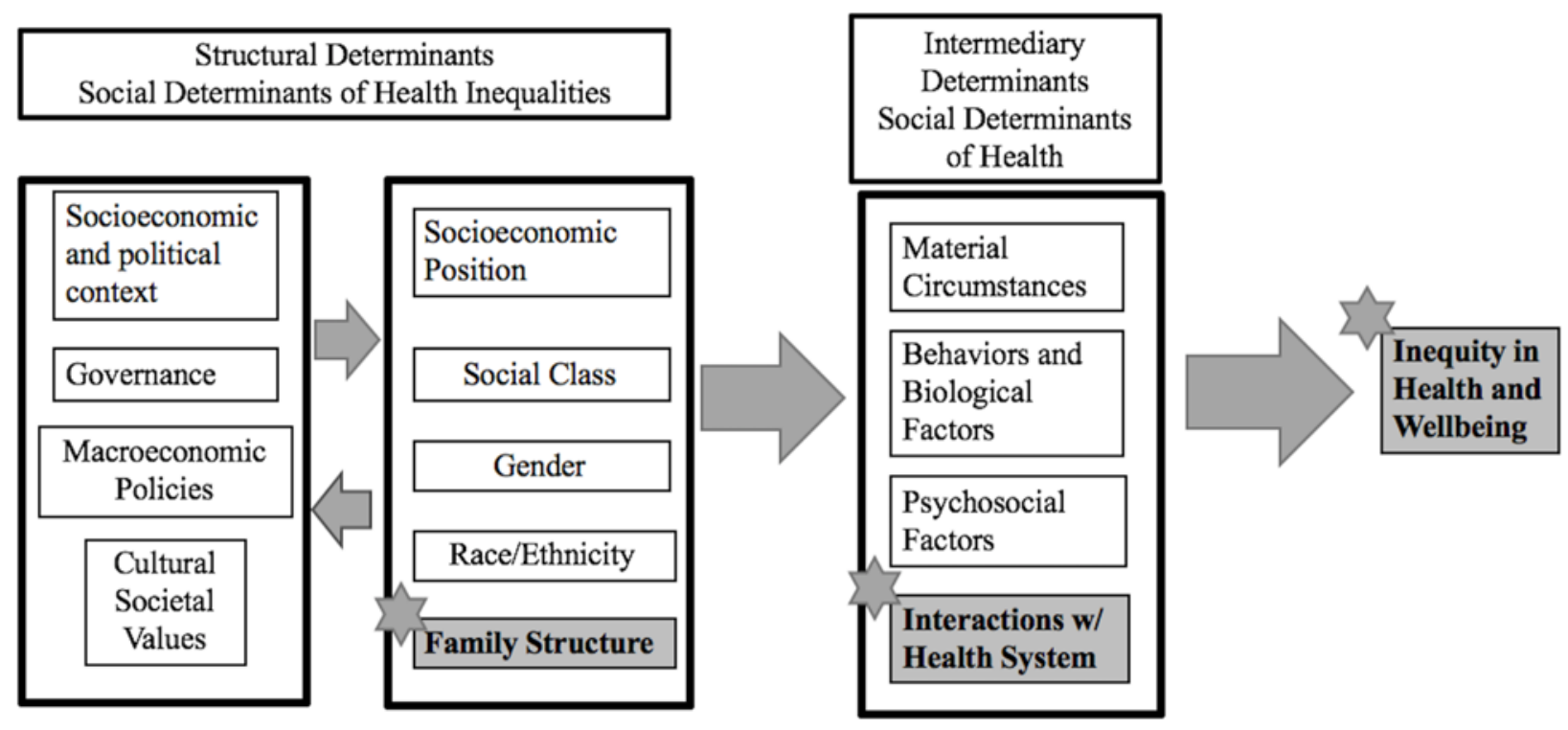

Note: Adapted from Commission on Social Determinants of Health conceptual framework

(WHO, 2010). This model proposes the conceptualization of family structure as a social

grouping that operates similarly to socioeconomic position, social class, gender, and

race/ethnicity in providing differential access to resources and care. Conceptual foci of this study are marked in bold/gray. 
Table 1.

Demographics and Descriptive Statistics for the Full Sample and for Each Family Structure.

\begin{tabular}{|c|c|c|c|c|c|c|}
\hline & $\begin{array}{c}\text { Married } \\
\text { Biological } \\
\text { Family } \\
(\mathrm{n}=5431)\end{array}$ & $\begin{array}{l}\text { Cohabiting } \\
\text { Biological } \\
\text { Family } \\
(\mathrm{n}=135)\end{array}$ & $\begin{array}{l}\text { Married } \\
\text { Stepfamily } \\
(\mathrm{n}=916)\end{array}$ & $\begin{array}{l}\text { Cohabiting } \\
\text { Stepfamily } \\
(\mathrm{n}=220)\end{array}$ & $\begin{array}{l}\text { Divorced/Separated } \\
\text { Single-Mother } \\
(\mathrm{n}=1520)\end{array}$ & $\begin{array}{c}\text { Never Married } \\
\text { Single-Mother } \\
\quad(n=518)\end{array}$ \\
\hline & $\%$ or $M \pm S D$ & $\%$ or $M \pm S D$ & $\%$ or $M \pm S D$ & $\%$ or $M \pm S D$ & $\%$ or $M \pm S D$ & $\%$ or $M \pm S D$ \\
\hline Male child & $57.9 \%$ & $60.0 \%$ & $57.9 \%$ & $59.1 \%$ & $55.3 \%$ & $57.9 \%$ \\
\hline Child age & $14.63 \pm 1.71$ & $14.67 \pm 1.78$ & $14.70 \pm 1.72$ & $14.37 \pm 1.81$ & $14.68 \pm 1.71$ & $14.32 \pm 1.73$ \\
\hline \multicolumn{7}{|l|}{ Child race } \\
\hline Hispanic & $7.6 \%$ & $19.3 \%$ & $9.1 \%$ & $18.6 \%$ & $11.3 \%$ & $12.7 \%$ \\
\hline White non-Hispanic & $80.0 \%$ & $59.3 \%$ & $72.7 \%$ & $57.3 \%$ & $64.5 \%$ & $30.9 \%$ \\
\hline Black non-Hispanic & $4.4 \%$ & $10.4 \%$ & $9.4 \%$ & $15.0 \%$ & $13.6 \%$ & $41.1 \%$ \\
\hline Other & $8.0 \%$ & $11.1 \%$ & $8.8 \%$ & $9.1 \%$ & $10.7 \%$ & $15.3 \%$ \\
\hline \multicolumn{7}{|l|}{ Maternal education } \\
\hline$<\mathrm{HS}$ & $4.8 \%$ & $20.0 \%$ & $7.5 \%$ & $17.7 \%$ & $9.7 \%$ & $13.5 \%$ \\
\hline HS graduate & $16.6 \%$ & $37.0 \%$ & $25.0 \%$ & $30.0 \%$ & $21.3 \%$ & $31.5 \%$ \\
\hline$>\mathrm{HS}$ & $78.6 \%$ & $43.0 \%$ & $67.5 \%$ & $52.3 \%$ & $69.0 \%$ & $55.0 \%$ \\
\hline \multicolumn{7}{|l|}{ Poverty level (PL) } \\
\hline At/below 100\% PL & $6.4 \%$ & $33.3 \%$ & $15.9 \%$ & $29.1 \%$ & $30.3 \%$ & $40.9 \%$ \\
\hline $100 \%-133 \%$ PL & $4.8 \%$ & $17.8 \%$ & $8.3 \%$ & $14.1 \%$ & $13.0 \%$ & $13.7 \%$ \\
\hline 133\%-150\% PL & $1.0 \%$ & $1.5 \%$ & $2.3 \%$ & $2.7 \%$ & $2.8 \%$ & $1.7 \%$ \\
\hline 150\%-185\% PL & $4.7 \%$ & $11.9 \%$ & $8.8 \%$ & $9.5 \%$ & $7.8 \%$ & $9.7 \%$ \\
\hline 185\%-200\% PL & $2.0 \%$ & $4.4 \%$ & $2.9 \%$ & $2.3 \%$ & $3.5 \%$ & $2.1 \%$ \\
\hline 200\%-300\% PL & $15.7 \%$ & $9.6 \%$ & $19.2 \%$ & $20.0 \%$ & $16.1 \%$ & $12.4 \%$ \\
\hline
\end{tabular}




\begin{tabular}{|c|c|c|c|c|c|c|}
\hline $300 \%-400 \%$ PL & $16.1 \%$ & $9.6 \%$ & $12.2 \%$ & $8.2 \%$ & $8.8 \%$ & $6.2 \%$ \\
\hline Above $400 \%$ PL & $49.3 \%$ & $11.9 \%$ & $30.2 \%$ & $14.1 \%$ & $17.7 \%$ & $13.3 \%$ \\
\hline Child has unmet health care need & $8.7 \%$ & $17.8 \%$ & $13.3 \%$ & $17.7 \%$ & $17.7 \%$ & $14.7 \%$ \\
\hline Child has IEP & $30.8 \%$ & $36.3 \%$ & $32.5 \%$ & $37.3 \%$ & $36.1 \%$ & $44.4 \%$ \\
\hline \# special health care needs & $1.86 \pm 1.47$ & $2.36 \pm 1.80$ & $2.03 \pm 1.58$ & $2.05 \pm 1.47$ & $2.22 \pm 1.78$ & $2.36 \pm 1.79$ \\
\hline Parent knows child's friends & $3.07 \pm 0.67$ & $2.98 \pm 0.83$ & $2.87 \pm 0.73$ & $2.92 \pm 0.76$ & $2.98 \pm 0.75$ & $2.95 \pm 0.80$ \\
\hline Parent-youth closeness & $3.55 \pm 0.62$ & $3.45 \pm 0.79$ & $3.46 \pm 0.68$ & $3.44 \pm 0.75$ & $3.49 \pm 0.70$ & $3.51 \pm 0.72$ \\
\hline
\end{tabular}

IEP=Individualized Education Plan 
Table 2.

Family Structure Differences in Family-Centered Care and Youth Development Outcomes.

\begin{tabular}{|c|c|c|c|c|c|c|c|}
\hline & $\begin{array}{c}\text { Married } \\
\text { Biological } \\
\text { Family } \\
(\mathrm{n}=5431)\end{array}$ & $\begin{array}{c}\text { Cohabiting } \\
\text { Biological } \\
\text { Family } \\
(\mathrm{n}=135)\end{array}$ & $\begin{array}{c}\text { Married } \\
\text { Stepfamily } \\
(\mathrm{n}=916)\end{array}$ & $\begin{array}{c}\text { Cohabiting } \\
\text { Stepfamily } \\
(\mathrm{n}=220)\end{array}$ & $\begin{array}{c}\text { Divorced/ } \\
\text { Separated } \\
\text { Single-Mother } \\
(\mathrm{n}=1520)\end{array}$ & $\begin{array}{c}\text { Never Married } \\
\text { Single-Mother } \\
\quad(n=518)\end{array}$ & \\
\hline & $\%$ or $M \pm S D$ & $\%$ or $M \pm S D$ & $\%$ or $M \pm S D$ & $\%$ or $M \pm S D$ & $\%$ or $M \pm S D$ & $\%$ or $M \pm S D$ & $F$ or $\chi^{2}$ \\
\hline Family-centered care & $3.54 \pm 0.55_{a}$ & $3.28 \pm 0.68_{b}$ & $3.43 \pm 0.64_{b}$ & $3.40 \pm 0.65 b$ & $3.42 \pm 0.67 \mathrm{~b}$ & $3.36 \pm 0.68_{b}$ & $24.58 * * *$ \\
\hline Youth flourishing & $3.97 \pm 0.67 \mathrm{a}$ & $3.77 \pm 0.79_{\mathrm{b}}$ & $3.71 \pm 0.78_{b}$ & $3.75 \pm 0.79_{\mathrm{b}}$ & $3.72 \pm 0.83_{b}$ & $3.74 \pm 0.83_{\mathrm{b}}$ & $46.59 * * *$ \\
\hline Extracurricular activities & $2.17 \pm 0.93_{\mathrm{a}}$ & $1.45 \pm 1.06_{\mathrm{b}}$ & $1.83 \pm 1.03_{\mathrm{c}}$ & $1.63 \pm 0.99_{\mathrm{bc}}$ & $1.69 \pm 1.03_{\mathrm{b}}$ & $1.63 \pm 1.05 \mathrm{~b}$ & $100.57 * * *$ \\
\hline Physical health is excellent & $48.7 \%$ & $37.0 \%$ & $38.6 \%$ & $34.5 \%$ & $36.6 \%$ & $29.7 \%$ & $145.48 * * *$ \\
\hline
\end{tabular}

Notes. Means in same row with different subscripts are significantly different at least $p<.05$. 
Table 3.

Regression Models Testing the Association between Family-Centered Care and Youth Flourishing in Married Biological Families, Married Stepfamilies, and Divorced/Separated Single-Mother Families.

\begin{tabular}{|c|c|c|c|c|c|c|c|c|c|}
\hline & \multicolumn{3}{|c|}{$\begin{array}{l}\text { Married Biological Family } \\
\qquad(\mathrm{n}=5431)\end{array}$} & \multicolumn{3}{|c|}{$\begin{array}{l}\text { Married Stepfamily } \\
\qquad(\mathrm{n}=916)\end{array}$} & \multicolumn{3}{|c|}{$\begin{array}{c}\text { Divorced/Separated Single- } \\
\text { Mother } \\
(\mathrm{n}=1520)\end{array}$} \\
\hline & $b$ & $S E$ & $\beta$ & $b$ & $S E$ & $\beta$ & $b$ & $S E$ & $\beta$ \\
\hline Male child & -0.19 & 0.02 & $-.14^{* * *}$ & -0.25 & 0.04 & $-.16^{* * *}$ & -0.21 & 0.04 & $-.13^{* * *}$ \\
\hline Child age & -0.01 & 0.01 & -.02 & 0.00 & 0.01 & .01 & -0.00 & 0.01 & -.01 \\
\hline \multicolumn{10}{|l|}{ Child race $^{\mathrm{a}}$} \\
\hline Black non-Hispanic & 0.08 & 0.04 & $.02 *$ & -0.03 & 0.08 & -.01 & -0.08 & 0.06 & -.03 \\
\hline Other & 0.09 & 0.03 & $.04 * *$ & 0.06 & 0.08 & .02 & -0.01 & 0.06 & -.00 \\
\hline Hispanic & 0.12 & 0.03 & $.05^{* * *}$ & 0.07 & 0.08 & .03 & 0.08 & 0.06 & .03 \\
\hline Maternal education & 0.04 & 0.02 & $.03 *$ & 0.01 & 0.04 & .01 & 0.04 & 0.03 & .03 \\
\hline Poverty level & -0.00 & 0.00 & -.01 & 0.00 & 0.01 & .01 & -0.00 & 0.01 & -.01 \\
\hline Child has unmet health care need & -0.03 & 0.03 & -.01 & -0.05 & 0.07 & -.02 & -0.03 & 0.05 & -.02 \\
\hline \# special health care needs & -0.11 & 0.01 & $-.24 * * *$ & -0.12 & 0.02 & $-.24 * * *$ & -0.09 & 0.01 & $-.18 * * *$ \\
\hline Has IEP & -0.10 & 0.02 & $-.07 * * *$ & -0.06 & 0.05 & -.04 & -0.12 & 0.04 & $-.07 * *$ \\
\hline Parent knows child's friends & 0.11 & 0.01 & $.11^{* * *}$ & 0.15 & 0.03 & $.14^{* * *}$ & 0.11 & 0.03 & $.10^{* * *}$ \\
\hline Parent-youth closeness & 0.29 & 0.01 & $.26^{* * *}$ & 0.37 & 0.03 & $.33 * * *$ & 0.37 & 0.03 & $.31 * * *$ \\
\hline Family-centered care & 0.13 & 0.02 & $.10^{* * *}$ & 0.13 & 0.04 & $.10^{* * *}$ & 0.16 & 0.03 & $.13^{* * *}$ \\
\hline$F(\mathrm{df})$ & \multicolumn{3}{|c|}{$143.00(13,5417)^{* * *}$} & \multicolumn{3}{|c|}{$32.43(13,902)^{* * *}$} & \multicolumn{3}{|c|}{$43.05(13,1506)^{* * *}$} \\
\hline$R^{2}$ & \multicolumn{3}{|c|}{.256} & \multicolumn{3}{|c|}{.319} & \multicolumn{3}{|c|}{.271} \\
\hline
\end{tabular}

Notes. ${ }^{a}$ White non-Hispanic is the referent group. ${ }^{*} p<.05$, ${ }^{* *} p<.01,{ }^{* * *} p<.001$, IEP=Individualized Education Plan 
Table 4.

Regression Models Testing the Association between Family-Centered Care and Youth Flourishing in Cohabiting Biological Families, Cohabiting Stepfamilies, and Never Married Single-Mother Families.

\begin{tabular}{|c|c|c|c|c|c|c|c|c|c|}
\hline & \multicolumn{3}{|c|}{$\begin{array}{l}\text { Cohabiting Biological } \\
\text { Family }(\mathrm{n}=135)\end{array}$} & \multicolumn{3}{|c|}{$\begin{array}{l}\text { Cohabiting Stepfamily } \\
\qquad(\mathrm{n}=220)\end{array}$} & \multicolumn{3}{|c|}{$\begin{array}{l}\text { Never Married Single- } \\
\text { Mother }(\mathrm{n}=518)\end{array}$} \\
\hline & $b$ & $S E$ & $\beta$ & $b$ & $S E$ & $\beta$ & $b$ & $S E$ & $\beta$ \\
\hline Male child & -0.13 & 0.13 & -.08 & -0.21 & 0.10 & $-.13^{*}$ & -0.19 & 0.06 & $-.11^{* *}$ \\
\hline Child age & -0.04 & 0.04 & -.09 & -0.05 & 0.03 & -.11 & -0.01 & 0.02 & -.03 \\
\hline \multicolumn{10}{|l|}{ Child race $^{\mathrm{a}}$} \\
\hline Black non-Hispanic & 0.43 & 0.21 & $.17^{*}$ & -0.02 & 0.14 & -.01 & -0.04 & 0.07 & -.02 \\
\hline Other & 0.14 & 0.20 & .06 & 0.27 & 0.17 & .10 & 0.01 & 0.10 & .00 \\
\hline Hispanic & 0.54 & 0.17 & $.27 * *$ & 0.01 & 0.13 & .01 & 0.01 & 0.10 & .01 \\
\hline Maternal education & -0.03 & 0.09 & -.03 & 0.07 & 0.07 & .07 & 0.06 & 0.05 & .05 \\
\hline Poverty level & -0.03 & 0.03 & -.08 & -0.01 & 0.02 & -.04 & -0.01 & 0.01 & -.02 \\
\hline Child has unmet health care need & -0.01 & 0.17 & -.00 & -0.05 & 0.13 & -.02 & -0.17 & 0.09 & -.07 \\
\hline \# special health care needs & -0.06 & 0.04 & -.13 & -0.09 & 0.04 & $-.17 *$ & -0.06 & 0.02 & $-.14^{* *}$ \\
\hline Has IEP & -0.25 & 0.16 & -.15 & -0.05 & 0.11 & -.03 & -0.21 & 0.07 & $-.13^{* *}$ \\
\hline Parent knows child's friends & 0.14 & 0.08 & .15 & -0.05 & 0.06 & -.04 & 0.15 & 0.04 & $.15^{* * *}$ \\
\hline Parent-youth closeness & 0.24 & 0.09 & $.24^{* *}$ & 0.48 & 0.07 & $.45^{* * *}$ & 0.42 & 0.05 & $.37 * * *$ \\
\hline Family-centered care & 0.06 & 0.10 & .05 & 0.11 & 0.08 & .10 & 0.04 & 0.05 & .04 \\
\hline$F(\mathrm{df})$ & \multicolumn{3}{|c|}{$3.73(13,121)^{* * *}$} & \multicolumn{3}{|c|}{$7.95(13,206)^{* * *}$} & \multicolumn{3}{|c|}{$18.41(13,504)^{* * *}$} \\
\hline$R^{2}$ & \multicolumn{3}{|l|}{.286} & \multicolumn{3}{|c|}{.334} & \multicolumn{3}{|c|}{.322} \\
\hline
\end{tabular}

Notes. ${ }^{a}$ White non-Hispanic is the referent group. ${ }^{*} p<.05,{ }^{* *} p<.01,{ }^{* * *} p<.001$, IEP=Individualized Education Plan 
Table 5.

Regression Models Testing the Association between Family-Centered Care and Youth Participation in Extracurricular Activities in Married Biological Families, Married Stepfamilies, and Divorced/Separated Single-Mother Families.

\begin{tabular}{|c|c|c|c|c|c|c|c|c|c|}
\hline & \multicolumn{3}{|c|}{$\begin{array}{l}\text { Married Biological Family } \\
\qquad(\mathrm{n}=5431)\end{array}$} & \multicolumn{3}{|c|}{$\begin{array}{l}\text { Married Stepfamily } \\
\quad(\mathrm{n}=916)\end{array}$} & \multicolumn{3}{|c|}{$\begin{array}{c}\text { Divorced/Separated Single- } \\
\text { Mother } \\
(\mathrm{n}=1520)\end{array}$} \\
\hline & $b$ & $S E$ & $\beta$ & $b$ & $S E$ & $\beta$ & $b$ & SE & $\beta$ \\
\hline Male child & -0.09 & 0.02 & $-.05 * * *$ & -0.13 & 0.07 & -.06 & -0.11 & 0.05 & $-.05 *$ \\
\hline Child age & -0.02 & 0.01 & $-.04 * *$ & 0.02 & 0.02 & .05 & -0.02 & 0.02 & -.04 \\
\hline \multicolumn{10}{|l|}{ Child race $^{\mathrm{a}}$} \\
\hline Black non-Hispanic & -0.03 & 0.06 & -.01 & 0.11 & 0.11 & .03 & -0.02 & 0.08 & -.01 \\
\hline Other & -0.00 & 0.04 & -.00 & 0.12 & 0.11 & .03 & 0.03 & 0.08 & .01 \\
\hline Hispanic & -0.04 & 0.05 & -.01 & 0.02 & 0.11 & .00 & -0.18 & 0.08 & $-.05^{*}$ \\
\hline Maternal education & 0.34 & 0.02 & $.20 * * *$ & 0.14 & 0.06 & $.09 *$ & 0.21 & 0.04 & $.13^{* * *}$ \\
\hline Poverty level & 0.07 & 0.01 & $.16^{* * *}$ & 0.05 & 0.01 & $.13^{* * *}$ & 0.06 & 0.01 & $.16^{* * *}$ \\
\hline Child has unmet health care need & 0.08 & 0.04 & .03 & 0.02 & 0.10 & .01 & 0.03 & 0.07 & .01 \\
\hline \# special health care needs & -0.08 & 0.01 & $-.13^{* * *}$ & -0.08 & 0.02 & $-.12^{* *}$ & -0.07 & 0.02 & $-.12 * * *$ \\
\hline Has IEP & -0.19 & 0.03 & $-.09 * * *$ & -0.24 & 0.08 & $-.11^{* *}$ & -0.15 & 0.06 & $-.07 *$ \\
\hline Parent knows child's friends & 0.13 & 0.02 & $.09 * * *$ & 0.16 & 0.05 & $.11^{* *}$ & 0.14 & 0.04 & $.10^{* * *}$ \\
\hline Parent-youth closeness & 0.08 & 0.02 & $.05 * * *$ & 0.14 & 0.05 & $.09 * *$ & 0.08 & 0.04 & $.05 *$ \\
\hline Family-centered care & 0.05 & 0.02 & $.03^{*}$ & 0.10 & 0.05 & .06 & 0.02 & 0.04 & .01 \\
\hline$F(\mathrm{df})$ & \multicolumn{3}{|c|}{$89.49(13,5417)^{* * *}$} & \multicolumn{3}{|c|}{$11.84(13,902)^{* * *}$} & \multicolumn{3}{|c|}{$18.57(13,1506)^{* * *}$} \\
\hline$R^{2}$ & \multicolumn{3}{|c|}{.177} & \multicolumn{3}{|c|}{.146} & \multicolumn{3}{|c|}{.138} \\
\hline
\end{tabular}

Notes. ${ }^{a}$ White non-Hispanic is the referent group. ${ }^{*} p<.05$, ${ }^{* *} p<.01,{ }^{* * *} p<.001$, IEP=Individualized Education Plan 
Table 6.

Regression Models Testing the Association between Family-Centered Care and Youth Participation in Extracurricular Activities in Cohabiting Biological Families, Cohabiting Stepfamilies, and Never Married Single-Mother Families.

\begin{tabular}{|c|c|c|c|c|c|c|c|c|c|}
\hline & \multicolumn{3}{|c|}{$\begin{array}{l}\text { Cohabiting Biological } \\
\text { Family }(\mathrm{n}=135)\end{array}$} & \multicolumn{3}{|c|}{$\begin{array}{l}\text { Cohabiting Stepfamily } \\
\qquad(\mathrm{n}=220)\end{array}$} & \multicolumn{3}{|c|}{$\begin{array}{l}\text { Never Married Single- } \\
\text { Mother }(\mathrm{n}=518)\end{array}$} \\
\hline & $b$ & $S E$ & $\beta$ & $b$ & $S E$ & $\beta$ & $b$ & $S E$ & $\beta$ \\
\hline Male child & -0.27 & 0.18 & -.12 & 0.28 & 0.13 & $.14^{*}$ & 0.01 & 0.09 & .00 \\
\hline Child age & -0.07 & 0.05 & -.11 & -0.04 & 0.04 & -.08 & -0.01 & 0.03 & -.02 \\
\hline \multicolumn{10}{|l|}{ Child race $^{\mathrm{a}}$} \\
\hline Black non-Hispanic & -0.16 & 0.29 & -.05 & 0.42 & 0.18 & $.15^{*}$ & 0.24 & 0.10 & $.11^{*}$ \\
\hline Other & 0.34 & 0.28 & .10 & 0.12 & 0.23 & .03 & 0.33 & 0.14 & $.11^{*}$ \\
\hline Hispanic & 0.23 & 0.24 & .09 & -0.12 & 0.18 & -.05 & 0.18 & 0.15 & .06 \\
\hline Maternal education & 0.21 & 0.13 & .15 & 0.07 & 0.10 & .05 & 0.25 & 0.07 & $.17 * * *$ \\
\hline Poverty level & 0.13 & 0.04 & $.31 * *$ & 0.08 & 0.03 & $.23 * * *$ & 0.06 & 0.02 & $.16^{* *}$ \\
\hline Child has unmet health care need & 0.26 & 0.24 & .10 & 0.08 & 0.18 & .03 & 0.00 & 0.13 & .00 \\
\hline \# special health care needs & -0.05 & 0.06 & -.09 & -0.00 & 0.05 & -.00 & -0.05 & 0.03 & -.08 \\
\hline Has IEP & 0.07 & 0.22 & .03 & -0.37 & 0.15 & $-.18^{*}$ & -0.12 & 0.10 & -.06 \\
\hline Parent knows child's friends & 0.15 & 0.12 & .11 & 0.15 & 0.09 & .12 & 0.13 & 0.06 & $.10^{*}$ \\
\hline Parent-youth closeness & 0.12 & 0.12 & .09 & 0.26 & 0.09 & $.20 * * *$ & 0.16 & 0.06 & $.11^{* *}$ \\
\hline Family-centered care & 0.26 & 0.13 & .16 & -0.16 & 0.10 & -.11 & -0.02 & 0.07 & -.01 \\
\hline$F(\mathrm{df})$ & \multicolumn{3}{|c|}{$2.75(13,121)^{* *}$} & \multicolumn{3}{|c|}{$4.26(13,206)^{* * *}$} & \multicolumn{3}{|c|}{$6.39(13,504)^{* * *}$} \\
\hline$R^{2}$ & \multicolumn{3}{|l|}{.228} & \multicolumn{3}{|l|}{.212} & \multicolumn{3}{|l|}{.145} \\
\hline
\end{tabular}

Notes. ${ }^{a}$ White non-Hispanic is the referent group. ${ }^{*} p<.05,{ }^{* *} p<.01$, ${ }^{* * *} p<.001$, IEP=Individualized Education Plan 
Table 7.

Logistic Regression Models Testing the Association between Family-Centered Care and Excellent Physical Health in Married Biological Families, Married Stepfamilies, and Divorced/Separated Single-Mother Families.

\begin{tabular}{|c|c|c|c|c|c|c|c|c|c|c|c|c|}
\hline & \multicolumn{4}{|c|}{$\begin{array}{l}\text { Married Biological Family } \\
\qquad(\mathrm{n}=5431)\end{array}$} & \multicolumn{4}{|c|}{$\begin{array}{l}\text { Married Stepfamily } \\
\qquad(\mathrm{n}=916)\end{array}$} & \multicolumn{4}{|c|}{$\begin{array}{l}\text { Divorced/Separated Single-Mother } \\
\qquad(\mathrm{n}=1520)\end{array}$} \\
\hline & $\mathrm{b}$ & $\mathrm{SE}$ & OR & $95 \%$ CI & $\mathrm{b}$ & $\mathrm{SE}$ & $O R$ & $95 \mathrm{CI}$ & $\mathrm{b}$ & $\mathrm{SE}$ & $O R$ & $95 \mathrm{CI}$ \\
\hline Male child & 0.29 & 0.06 & $1.33^{* * *}$ & {$[1.19,1.49]$} & 0.32 & 0.15 & $1.37^{*}$ & {$[1.03,1.82]$} & 0.46 & 0.12 & $1.58 * * *$ & {$[1.26,1.98]$} \\
\hline Child age & -0.01 & 0.02 & 0.99 & {$[0.96,1.02]$} & -0.03 & 0.04 & 0.97 & {$[0.90,1.05]$} & -0.02 & 0.03 & 0.98 & {$[0.92,1.04]$} \\
\hline \multicolumn{13}{|l|}{ Child race $^{\mathrm{a}}$} \\
\hline Black non-Hispanic & -0.40 & 0.14 & $0.67 * *$ & {$[0.51,0.89]$} & -0.35 & 0.25 & 0.71 & {$[0.43,1.16]$} & -0.00 & 0.17 & 1.00 & {$[0.72,1.40]$} \\
\hline Other & -0.05 & 0.11 & 0.95 & {$[0.77,1.18]$} & 0.51 & 0.25 & $1.66^{*}$ & {$[1.03,2.69]$} & -0.25 & 0.19 & 0.78 & {$[0.53,1.14]$} \\
\hline Hispanic & -0.03 & 0.12 & 0.97 & {$[0.78,1.22]$} & -0.31 & 0.26 & 0.73 & {$[0.44,1.23]$} & -0.28 & 0.20 & 0.76 & {$[0.52,1.11]$} \\
\hline Maternal education & 0.28 & 0.06 & $1.32 * * *$ & {$[1.17,1.50]$} & 0.03 & 0.13 & 1.03 & {$[0.80,1.33]$} & 0.15 & 0.10 & 1.16 & {$[0.96,1.41]$} \\
\hline Poverty level & 0.13 & 0.02 & $1.14^{* * *}$ & {$[1.10,1.17]$} & 0.04 & 0.03 & 1.04 & {$[0.98,1.11]$} & 0.13 & 0.02 & $1.14^{* * *}$ & {$[1.09,1.19]$} \\
\hline $\begin{array}{l}\text { Child has unmet } \\
\text { health care need }\end{array}$ & -0.25 & 0.11 & $0.78 *$ & {$[0.62,0.96]$} & 0.11 & 0.24 & 1.12 & {$[0.70,1.78]$} & -0.44 & 0.17 & $0.64 * *$ & {$[0.46,0.90]$} \\
\hline \# SHCNs & -0.29 & 0.03 & $0.75^{* * *}$ & {$[0.72,0.79]$} & -0.31 & 0.06 & $0.74^{* * *}$ & {$[0.65,0.84]$} & -0.29 & 0.05 & $0.75^{* * *}$ & {$[0.68,0.82]$} \\
\hline Has IEP & 0.31 & 0.07 & $1.36 * * *$ & {$[1.18,1.56]$} & 0.42 & 0.17 & $1.52 *$ & {$[1.08,2.13]$} & 0.11 & 0.14 & 1.12 & {$[0.86,1.45]$} \\
\hline $\begin{array}{l}\text { Parent knows child's } \\
\text { friends }\end{array}$ & 0.09 & 0.05 & $1.09 *$ & {$[1.00,1.20]$} & 0.05 & 0.10 & 1.05 & {$[0.86,1.28]$} & 0.01 & 0.08 & 1.18 & {$[0.86,1.18]$} \\
\hline $\begin{array}{l}\text { Parent-youth } \\
\text { closeness }\end{array}$ & 0.17 & 0.05 & $1.19 * * *$ & {$[1.08,1.31]$} & 0.00 & 0.11 & 1.00 & {$[0.80,1.25]$} & 0.07 & 0.09 & 1.08 & {$[0.90,1.29]$} \\
\hline Family-centered care & 0.48 & 0.06 & $1.62 * * *$ & {$[1.44,1.81]$} & 0.40 & 0.12 & $1.49 * *$ & {$[1.16,1.90]$} & 0.25 & 0.10 & $1.28^{* *}$ & {$[1.06,1.55]$} \\
\hline$\chi^{2}(13)$ & \multicolumn{4}{|c|}{$559.45 * * *$} & \multicolumn{4}{|c|}{$68.98 * * *$} & \multicolumn{4}{|c|}{$1.84 .52 * * *$} \\
\hline
\end{tabular}

Notes. ${ }^{a}$ Referent group=White non-Hispanic. SHCN=Special Health Care Need. IEP=Individualized Education Plan ${ }^{*} p<.05$, ${ }^{* *} p<.01$, ${ }^{* * *} p<$ .001 . 
Table 8.

Logistic Regression Models Testing the Association between Family-Centered Care and Excellent Physical Health in Cohabiting Biological Families, Cohabiting Stepfamilies, and Never Married Single-Mother Families.

\begin{tabular}{|c|c|c|c|c|c|c|c|c|c|c|c|c|}
\hline & \multicolumn{4}{|c|}{$\begin{array}{l}\text { Cohabiting Biological Family } \\
\qquad(\mathrm{n}=135)\end{array}$} & \multicolumn{4}{|c|}{$\begin{array}{l}\text { Cohabiting Stepfamily } \\
\qquad(\mathrm{n}=220)\end{array}$} & \multicolumn{4}{|c|}{$\begin{array}{l}\text { Never Married Single-Mother } \\
\qquad(\mathrm{n}=518)\end{array}$} \\
\hline & $\mathrm{b}$ & $\mathrm{SE}$ & OR & $95 \mathrm{CI}$ & $\mathrm{b}$ & $\mathrm{SE}$ & $O R$ & $95 \mathrm{CI}$ & $\mathrm{b}$ & $\mathrm{SE}$ & OR & $95 \mathrm{CI}$ \\
\hline Male child & 0.32 & 0.43 & 1.37 & {$[0.59,3.20]$} & 0.81 & 0.33 & $2.24^{*}$ & {$[1.17,4.28]$} & 0.04 & 0.21 & 1.05 & {$[0.70,1.57]$} \\
\hline Child age & 0.03 & 0.12 & 1.03 & {$[0.81,1.30]$} & -0.08 & 0.09 & 0.92 & {$[0.78,1.09]$} & 0.07 & 0.06 & 1.07 & {$[0.95,1.20]$} \\
\hline \multicolumn{13}{|l|}{ Child race $^{\mathrm{a}}$} \\
\hline Black non-Hispanic & 0.13 & 0.64 & 1.14 & {$[0.33,3.96]$} & 0.03 & 0.45 & 1.03 & {$[0.43,2.48]$} & 0.24 & 0.24 & 1.27 & {$[0.80,2.03]$} \\
\hline Other & -1.39 & 0.87 & 0.25 & {$[0.05,1.38]$} & -0.17 & 0.60 & 0.84 & {$[0.26,2.71]$} & -0.16 & 0.33 & 0.86 & {$[0.45,1.64]$} \\
\hline Hispanic & 0.18 & 0.54 & 1.19 & {$[0.41,3.44]$} & -0.30 & 0.46 & 0.74 & {$[0.30,1.83]$} & -0.12 & 0.34 & 0.89 & {$[0.46,1.73]$} \\
\hline Maternal education & -0.06 & 0.31 & 0.95 & {$[0.52,1.73]$} & -0.09 & 0.24 & 0.91 & {$[0.57,1.46]$} & 0.28 & 0.16 & 1.32 & {$[0.96,1.82]$} \\
\hline Poverty level & 0.13 & 0.09 & 1.13 & {$[0.95,1.35]$} & 0.14 & 0.06 & $1.16^{*}$ & {$[1.02,1.31]$} & 0.06 & 0.04 & 1.06 & {$[0.98,1.15]$} \\
\hline $\begin{array}{l}\text { Child has unmet } \\
\text { health care need }\end{array}$ & -1.00 & 0.68 & 0.37 & {$[0.10,1.40]$} & 0.13 & 0.45 & 1.14 & {$[0.48,2.75]$} & -0.48 & 0.32 & 0.62 & {$[0.33,1.16]$} \\
\hline \# SHCNs & -0.66 & 0.21 & $0.52 * *$ & {$[0.35,0.78]$} & -0.21 & 0.14 & 0.81 & {$[0.61,1.07]$} & -0.27 & 0.08 & $0.77^{* * *}$ & {$[0.66,0.89]$} \\
\hline Has IEP & 0.96 & 0.54 & 2.62 & {$[0.91,7.56]$} & 0.19 & 0.37 & 1.22 & {$[0.59,2.49]$} & 0.50 & 0.23 & $1.64^{*}$ & {$[1.04,2.59]$} \\
\hline $\begin{array}{l}\text { Parent knows child's } \\
\text { friends }\end{array}$ & -0.41 & 0.29 & 0.66 & {$[0.38,1.16]$} & 0.25 & 0.22 & 1.28 & {$[0.84,1.96]$} & -0.10 & 0.14 & 0.90 & {$[0.69,1.18]$} \\
\hline $\begin{array}{l}\text { Parent-youth } \\
\text { closeness }\end{array}$ & -0.24 & 0.29 & 0.78 & {$[0.45,1.38]$} & 0.14 & 0.23 & 1.15 & {$[0.73,1.81]$} & 0.36 & 0.17 & $1.43^{*}$ & {$[1.03,1.98]$} \\
\hline Family-centered care & 0.26 & .32 & 1.30 & {$[0.69,2.45]$} & 0.41 & 0.27 & 1.50 & {$[0.89,2.55]$} & -0.03 & 0.16 & 0.98 & {$[0.72,1.32]$} \\
\hline$\chi^{2}(13)$ & $29.20^{* *}$ & & & & $24.76^{*}$ & & & & $37.06 *$ & & & \\
\hline
\end{tabular}

Notes. ${ }^{a}$ Referent group=White non-Hispanic. SHCN=Special Health Care Need. IEP=Individualized Education Plan ${ }^{*} p<.05$, ${ }^{* *} p<.01$, ${ }^{* *} p<$ .001 . 